Asian Australas. J. Biosci. Biotechnol. 2020, 5 (2), 48-59

Asian-Australasian Journal of

Bioscience and Biotechnology

ISSN 2414-1283 (Print) 2414-6293 (Online)

www.ebupress.com/journal/aajbb

\title{
Article \\ Status of drying fish, marketing channel and associated problems in the Kuakata coast of Patuakhali district, Bangladesh
}

\author{
Md. Jabir Al Mehedi ${ }^{1}$, Al-Shahriar ${ }^{2 *}$,Sk. Musfiq-ul-Haque Fahim ${ }^{3}$ and Md. Gias Uddin ${ }^{4}$ \\ ${ }^{1}$ Department of Marine Fisheries and Oceanography, Patuakhali Science and Technology University, Dumki, \\ Patuakhali-8602, Bangladesh \\ ${ }^{2}$ Department of Fisheries Technology, Bangladesh Agricultural University, Mymensingh-2202, Bangladesh \\ ${ }^{3}$ Fisheries Officer, PSKS, Partner Organization of PKSF, Gangni, Meherpur, Bangladesh \\ ${ }^{4}$ Upazilla Aquaculture Extension Manager, CODEC, Bagerhat-9300, Bangladesh
}

*Corresponding author: Al-Shahriar, Department of Fisheries Technology, Bangladesh Agricultural University, Mymensingh-2202, Bangladesh. Phone: +8801761962245; E-mail: alshahriar12@ gmail.com

Received: 02 July 2020/Accepted: 12 August 2020/ Published: 31 August 2020

\begin{abstract}
The present study was conducted to know the fish drying activities, species used in fish drying and marketing channel of dried fish in Kuakata coast of Patuakhali district of Bangladesh. Sea fishes are mostly used for drying and dry fish producers collected raw fishes from arat (landing centers) (70\%), fishermen (25\%) and little amount from own capture (5\%). It was found that 21 fish species were used for drying among them 3 species (Harpadon nehereus, Setipinna phasa, Lepturacanthus savala) were commonly used and other 18 species were fairly used. The peak fish drying season was observed at mid-October to mid-February (in Bengali Kartik to Magh). It was observed that the dry fish producers used salt to produce good quality dry fish and salt mixing rate is $2 \mathrm{~kg}$ salt for $30-35 \mathrm{~kg}$ raw fish. The duration of drying at normal weather condition is varied between 3-5 days depending on the size of fishes. After drying, the dried fishes were packed in either jute bags or polythene bags and stored at room temperature for marketing. About $95 \%$ dried fish products are sold in the wholesale market at Chittagong, Syedpur, and Dhaka and rest 5\% sold to the local retail market. However, three (3) step dried fish marketing channels were observed in the study area. The producers sold their product at very lower price and it ranged between Tk. 120-3200 per Kg. The retail price of the dried fishes ranged from Tk. 200-3500 per Kg. The dry fish producers and intermediaries faced various problems like inadequate capital, natural calamities, lack of scientific knowledge and technology, price instability, lack of transport facilities, inadequate storage facilities, lack of physical marketing facilities and marketing information.
\end{abstract}

Keywords: dry fish; dry fish producers; marketing channel; price; problems

\section{Introduction}

Fish and fisheries play an important role in the economy of Bangladesh. There are 260 freshwater, 24 exotic, 475 species of marine fish species, 36 shrimp and 24 species of prawn (Rahman, 1989; Hussain et al., 1999) available in the waterbody of Bangladesh. Being a riverine country with a high potential aquatic resource, fish plays a vital role in the daily life of many people in Bangladesh. More than $11 \%$ people of total population directly or indirectly depend on fisheries sector for their livelihood (DoF, 2018). Sun drying of fishes is a simple and the oldest known method of fish preservation where fishes are dried under the sun. It is still a vital method of fish processing in the developing regions of the world. Traditional sun-drying is carried out in the open air, using the energy of the sun to evaporate the water and air flows to carry away the vapor. Theoretically, moisture content of the final product should be reduced to less than $15-16 \%$ where most of the microbiological and enzymatic activities are slowed down or stopped. The production of sun-dried fish has been increasing 
acceptability by the people. Dried fish is an important source of protein in Bangladesh. It is relished by many people of coastal, central and North-eastern districts (Nowsad, 2007). Dry fish (shutki) is one of the popular food items and is widely consumed in Bangladesh. Although, the physical and organoleptic qualities of many traditional sun-dried products are still un-satisfactory for human consumption (Nowsad, 2005). Many people of Bangladesh depend on the fish drying industry. Now a day's dry fish plays an important role in the economy of Bangladesh. In the fiscal year of 2013-2014, Bangladesh exported a total of 2634 MT of dry fishes which nearly earn 29.67 crore taka and contributed 2.09\% in the total export value of Bangladesh (DoF, 2015). Several studies on dry fish and its marketing system in Bangladesh had been conducted by many researchers (Fersoushi et al., 2015; Shamin et al., 2014; Amin et al., 2012; Monir et al., 2012; Sultana, 2011; Flowra et al., 2010; Nayeem et al., 2010; Samad et al., 2009; Hafiza, 2008). Generally dry fish and fishery products are marketed through many different channels and outlets in Bangladesh (Reza et al., 2005; Nayeem et al., 2010). Dried fish market of Asadganj, Chittagong is the largest dried fish market of Bangladesh. Fish drying is carried out in some selected parts of Bangladesh where modern preservation facilities and good infrastructure for transportation are absent. The methods employed for handling and processing of fish in Bangladesh are still traditional and need lot of improvement. All kinds of dried fish usually go to Asadganj dried fish market from all dried fish processing area of Bangladesh like Sonadia, Kotubdia, Talipotti, Saint Martin, Teknaf, Rangabali, Kuakata, Banshkhali, Anowara, Moheshkhali, Cox's Bazar, Noakhali, Chandpur, Khulna, Sathkira etc. These dried fish later supplied to different markets like Chittagong hill tracts, Sylhet, Dhaka, Comilla, Rangpur, Mymensingh, Rajsahi, Khulna, Bogora and all other parts of Bangladesh. It is also supplied to the foreign market such as Singapore, Hong Kong, Malaysia, United Kingdom, United States of America; United Arab Emirates etc. (Kleih et al., 2003). The main sources of dry fish in Barisal division are Kuakata, Alipur, Mohipur in Patuakhali, Charfassion in Bhola and small amount at Pathorghata in Barguna district. Considering these Kuakata dry fish markets was favored and selected for the present study. Dried sea fish mainly prepared at Skutki Palli and on some islands of Kuakata. Skutki Palli is just a few miles away from Kuakata sea beach. During season, Skutki Palli is full of fish that dried up. Thousands of people depend on this. Fisherman catches many types of fish from the sea. They sell some fresh fish and rest of the fish is use to make dry. There are varieties of fish process here. From Skutki Palli, Skutki or dry fish is supplied in many places of Bangladesh and also export in many countries. A major problem associated with sun drying of fish is the infestation of the products by the fly and insect larvae during drying and storage which deteriorate the products before consumption (Ahmed et al., 1978). The reasons for the less value addition at producer level are presumed to be the poor product quality and lack of market access due to various institutional and non- institutional barriers, e.g. high transportation cost/toll/taxation, price exploitative market players between producer and consumers, unexpected rain etc. A better knowledge on quality and safety of sun-dried fish is important because a reasonable quantity of sun-dried fish is exported to International market every year. To continue export of this fishery product the quality and safety of the product should be assured. At the same time, the product should have desired quality and it should be safe for health of the domestic consumers. With the above information, the present study was conduction to know the present status of dried products, species used, problems, marketing channel of dried fish in Kuakata coast of Patuakhali district, Bangladesh.

\section{Materials and Methods}

\subsection{Location and description of the study area}

Kuakata, locally known as "Sagar Kannya" (Daughter of the Sea) is a rare scenic beauty place on the southernmost tip of Bangladesh. Kuakata is situated Latachapli union under Kalapara Upazila of Patuakhali district and about $30 \mathrm{~km}$ in length and $6 \mathrm{~km}$ in breadth. It is $70 \mathrm{~km}$ from Patuakhali district headquarters and 320

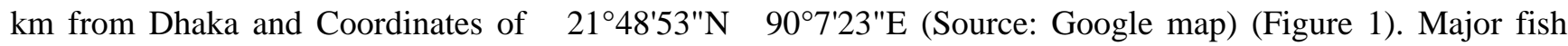
drying area of Kuakata is Kuakata beach drying yard, Alipur and Mohipur. Among them Kuakata beach drying yard was selected for fish drying activities and retailers from kuakata beach dry fish market. 


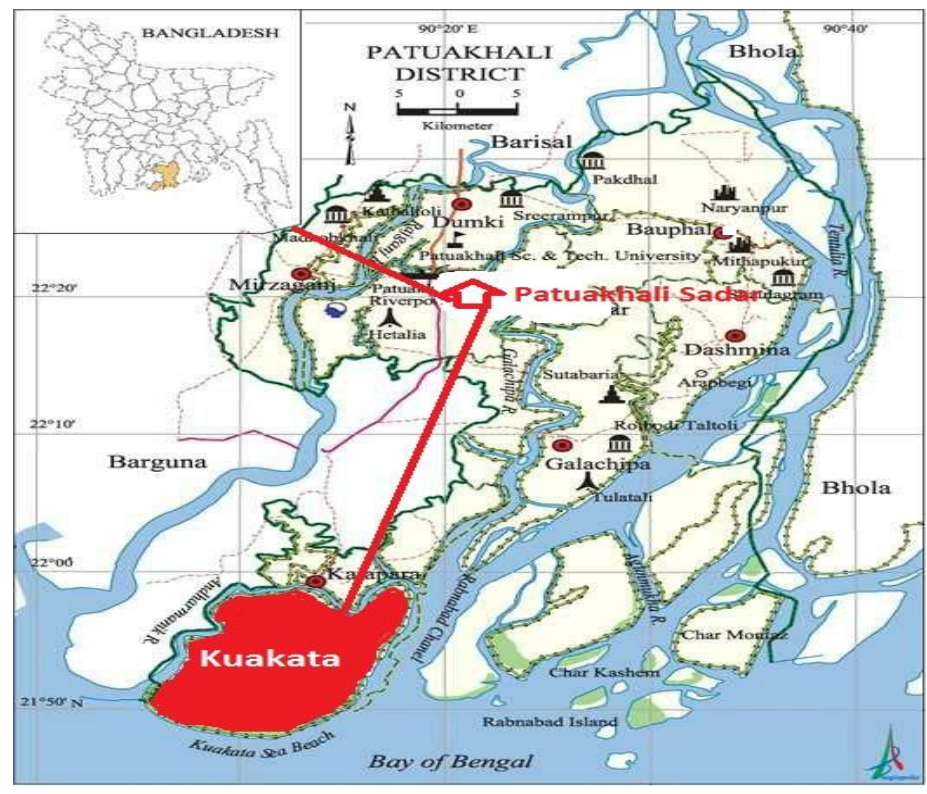

Figure 1. Geographical location of the study areas.

\subsection{Method of Data collection and study period}

The questionnaire interviews were taken through random sampling method. For this purpose, nineteen (19) dry fish producers and nineteen (19) dry fish retailers were selected from kuakata beach dry fish market. The study was conducted for a period of 5 months from August 2019 to December 2019. For questionnaire survey, fish retailers were selected through simple random sampling method. Interviews were conducted at the market during marketing time. Retailers took part in fish selling activities; as a result, there was a scope to observe the marketing activities. Primary data was collected by face to face interview. Secondary data was mainly collected from various books of DoF. Cross check interviews were conducted with key informants such as Upazila Fisheries Officer (UFO), and relevant GO and NGO officers. Fish drying process was observed in the drying spots of the study areas.

\subsection{Data processing and analysis}

After collection of data, these data were edited and coded. All the collected data were summarized carefully and tabulated. In order to minimize error, data were collected in local units and later local units were converted into standard units and the data were transferred to the tabulation sheet. The Likert scale with values of 4, 3, 2 and 1 was developed to determine problems faced by dry fish producers and retailers in the study area followed by Ali et al., (2017). In this way the dry fish producers and retailers were asked to rate their problem as very critical, critical, extent critical and not critical. The variable mean score of 2.5 was used to discover whether the factor in question was critical or not. The variables with mean score of 2.5 and above were considered critical while variable with less than 2.5 were not. The data was processed and finally analyzed using Microsoft Excel Program. At each stage of the survey, data were checked up, edited, coded and transferred into computer.

\section{Results}

\subsection{Sources of raw fish}

People of the study area carry out sun drying of fishes for mainly business and a little for household consumption. It was observed that large amount raw fishes were collected by the dry fish producers in the peak harvesting season from mid-October to mid-February (in Bengali Kartik to Magh) due to availability of raw fish and low market price. Generally, dry fish producers collected raw fishes from arat (landing centers) (70\%) and a little amount directly from fishermen $(25 \%)$ if the fisherman's boats which carry fresh fish are placed into dry fish processing area. Sometimes, dry fish producers go to the sea with their small boat to get raw fish for drying purpose $(5 \%)$ (Figure 2). It was observed that sometimes poor-quality raw materials were used for drying purpose. 


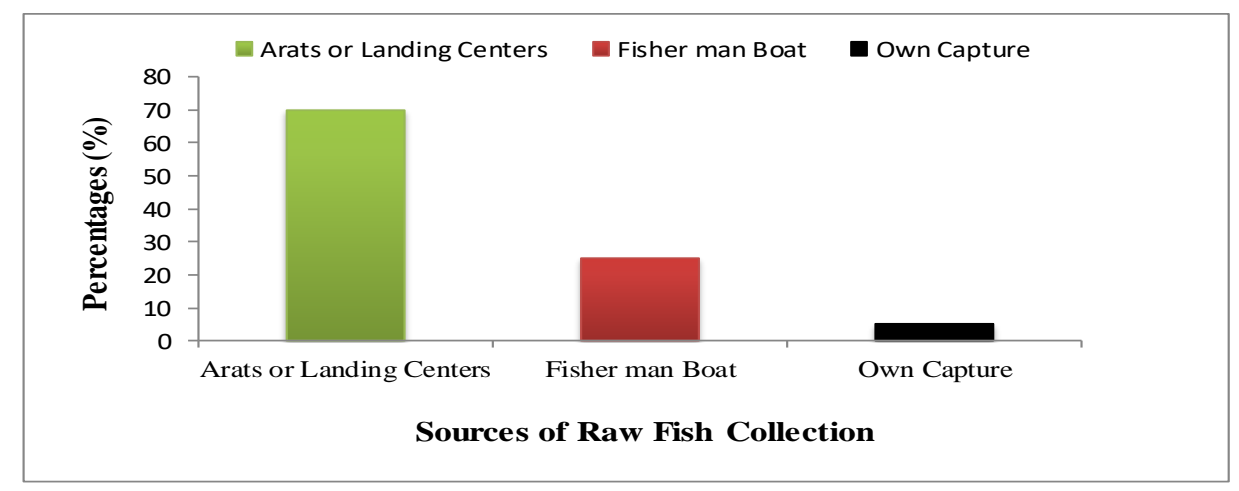

Figure 2. Raw fish collection sources.

Collection of raw fish generally depended on high tide locally called "Joba" in the river or sea. Each month consisted of three to four joba and each joba lasting for two to three days. Dry fish producer collected raw fish in each month for ten to twelve days. It was observed that raw fishes were transported from fish landing to fish drying centers generally by normal van, small boat and sometimes by head load.

\subsection{Species used in sun drying}

Different type of fishes is being used for sun drying in the study area. A total of twenty-one (21) fish species were identified that were used for drying (Table 1). Major categories include those fish, which are targeted by the dry fish farmers to be dried and minor species include different fish species that remain mixed with major fish species in small quantity. From their point of view fish species that are used in sun drying can be divided into two main categories (i) major fish species (80\% of total dried fish; Loittya, Faissa, Churi etc.) and (ii) minor fish species (20\% of total dried fish; Shapla pata, poa, chingri, koral, Ramsos, Rupchanda, Lakkha, Rupsha, Bhata etc).

Table 1. Species used for sun drying in the study area.

\begin{tabular}{|c|c|c|c|c|}
\hline $\begin{array}{l}\text { Sl. } \\
\text { No. }\end{array}$ & Scientific name & Common name & Local name & Availability \\
\hline 01 & Harpadon nehereus & Bombay Duck & Loittya & Common \\
\hline 02 & Setipinna phasa & Gangetic hairfin anchovy & Modhu faissa & Common \\
\hline 03 & Lepturacanthus savala/Trichiurus lepturus & Savalani hairtail & Churi & Common \\
\hline 04 & Himantura bleekeri & Pale edged stingray & Shapla pata & Few \\
\hline 05 & Gudusia chapra & Indian River shad & Chapila & Few \\
\hline 06 & Panna microdon/Johnious argentatus & Silver jew & Poa, Lal poa & Few \\
\hline 07 & Peneaeus sp. & Giant tiger shrimp & Chingri & Few \\
\hline 08 & Lates calcarifer & Sea bass & Koral & Few \\
\hline 09 & Tenualosa ilisha & Indian River shad & Nona Ilish & Few \\
\hline 10 & $\begin{array}{l}\text { Polynemus paradiseus/ } \\
\text { Sarotherodon melanotheron heudelotii }\end{array}$ & Paradise threadfin & Taposi, Ramshos & Few \\
\hline 11 & Devario devario & Banspata & Baspata & Few \\
\hline 12 & Pampus chinensis/Stromateus chinensis & Chinese pomfret & $\begin{array}{l}\text { Rup chanda, Choto } \\
\text { rupchanda }\end{array}$ & Few \\
\hline 13 & Scomberomorus guttatus & Spotted sea fish & Surma & Few \\
\hline 14 & Polynemus indicus & Indian salmon & Lakka & Few \\
\hline 15 & Xenentodon cancila & Needlefish & Kaikla & Few \\
\hline 16 & Scoliodon sorrakowah & Hammer headed shark & Hangor & Few \\
\hline 17 & Raiamas bola & Trout barb & Bhol & Few \\
\hline 18 & Mastacenbelus armatus & Zig-zag eel & Sona bain & Few \\
\hline 19 & Katsuwonus pelamis & Skipjack tuna & Rupsha & Few \\
\hline 20 & Mugil cephalus & Striped mullet & Bata & Few \\
\hline 21 & Mystus sp. & Striped dwarf catfish & Kata, Tengra & Few \\
\hline
\end{tabular}

Among twenty-one (21) species, on the basis of availability three (3) species were found commonly, eighteen (18) species were a little or few for drying. 


\subsection{Fish drying season}

It was observed that most of the dry fish producers start fish drying activity mainly in mid-October and continued to mid-June (in Bengali from Kartik to end of Baishakh or a little up to Jaistho). From mid-September to October (In Bengali from Aswin to mid Kartik), dry fish producer was spending their time to build bamboo made rack, pool or chatai for conducting drying activity. However, the peak season of fish drying was observed mid-October to mid-February (in Bengali Kartik to Magh) (Figure 3). Sufficient sunlight was available during that time and wind moisture content was less which enabled proper drying of fish.

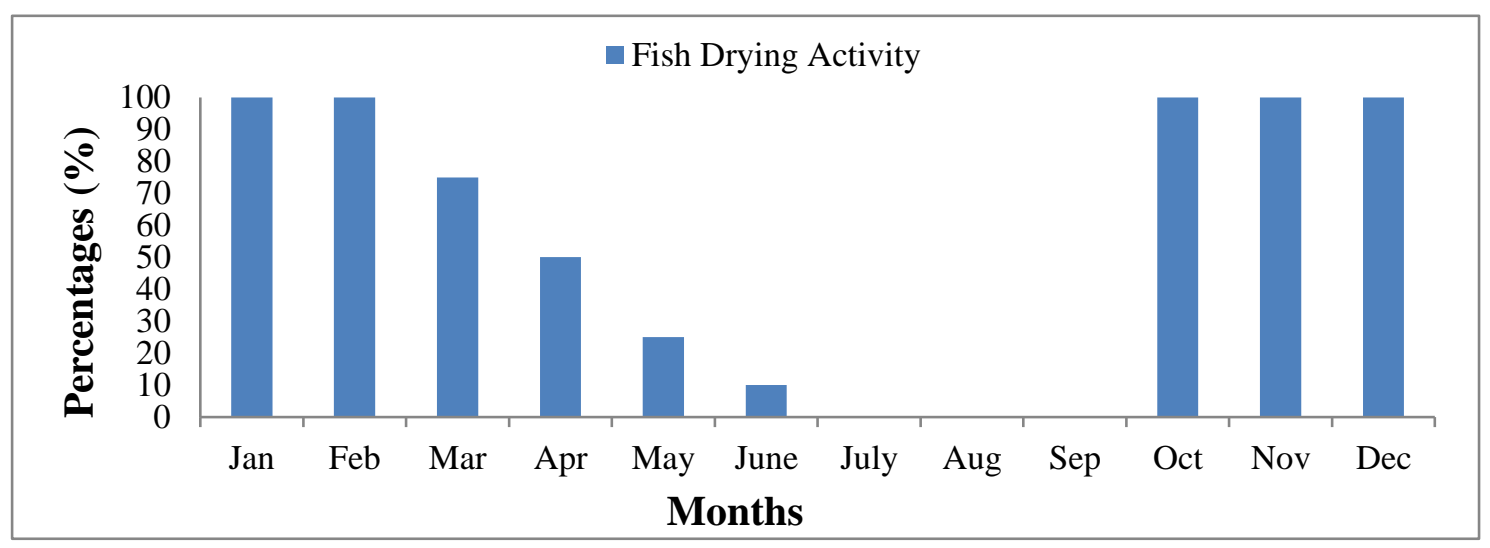

Figure 3. Fish drying season.

It was found that almost all the dried fish producer spends around whole day (12 to 15 hours) in peak season for fish drying activities. Sometimes women were worked in fish drying activity.

\subsection{Method of sun drying and Collection of raw fish}

Different activities were done before drying the fish including sorting, scaling, gutting, dressing, washing, salting, drying and marketing in the study area (Figures 4 and 5). It was observed that sorting was performed mainly on the drying yard for separating the small and large fishes. Dry fish producers collect raw fishes from local fish markets called arat or landing centers and directly from fishermen.

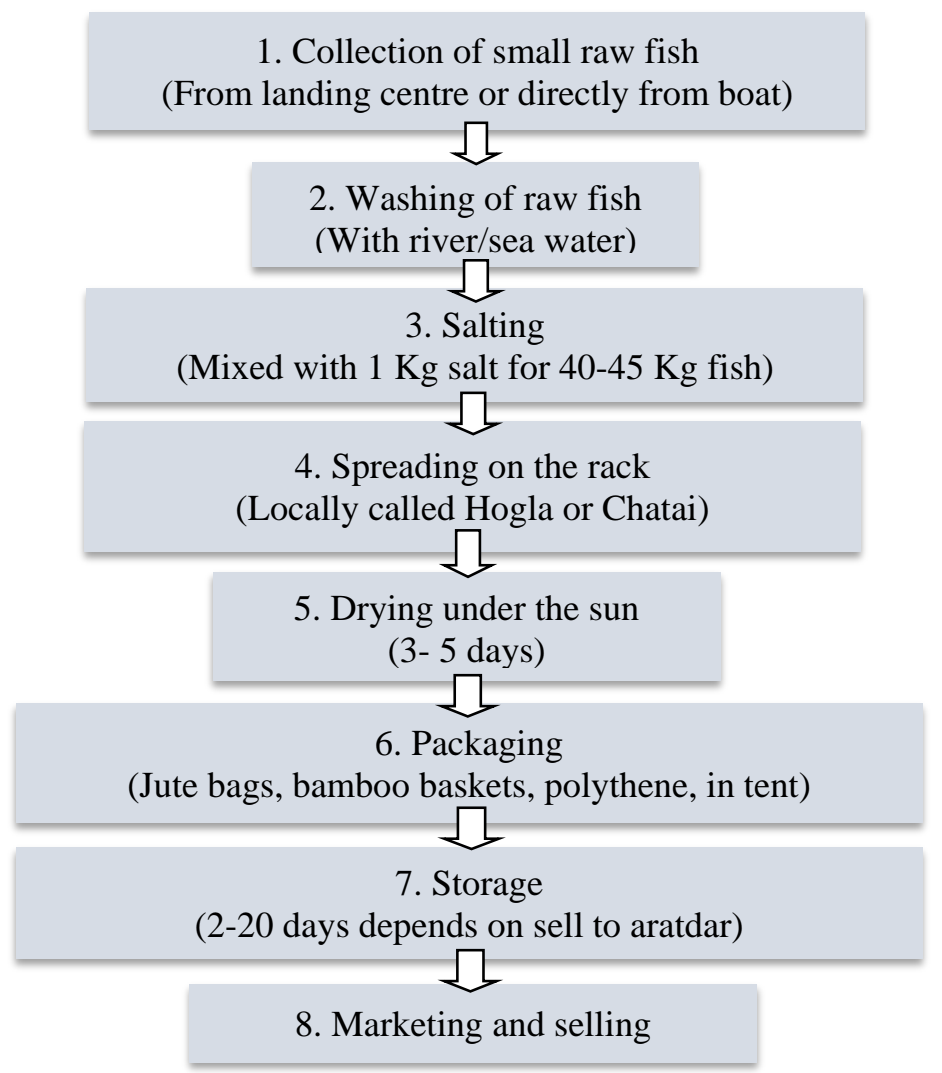

Figure 4. Flow chart for drying activities of small fishes. 


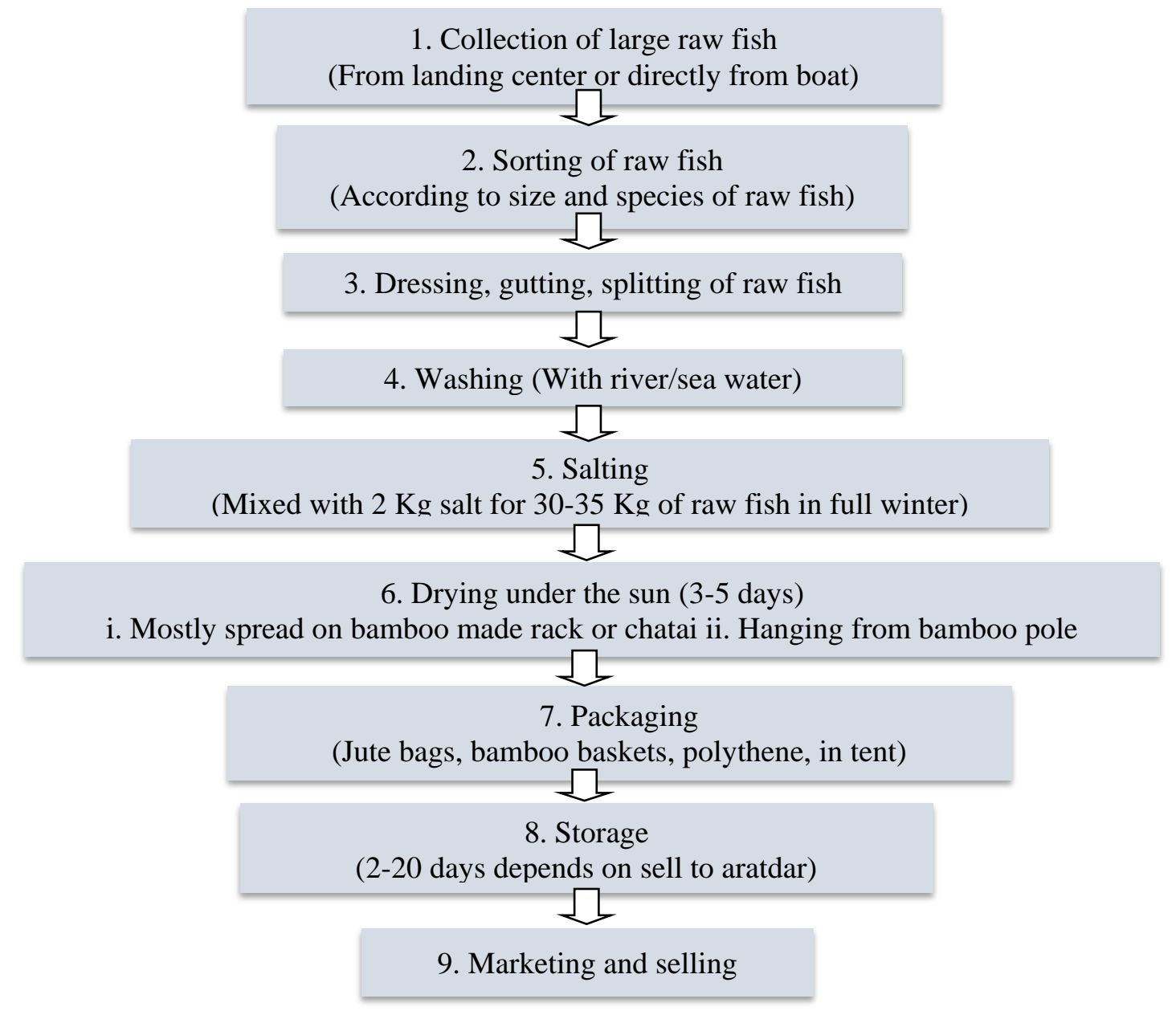

Figure 5. Flow chart for drying activities of large fishes in the study area.

In the study area most of the dry fish producers used mostly river or sea water for washing the raw fishes due to unavailability of tube well water or any other clean water sources.

\subsection{Packaging and storage}

For packaging sometimes bamboo baskets were also used for this purpose. If air didn't enter into the bags then the bags could be stored for 1 to 1.5 months. In some cases, dry fish producers stored the dried fishes in a tent generally made of thin plastic sheet and bamboo splits at drying yard places. Packed dried fishes were kept into these tents for temporary storage until marketing or selling.

\subsection{Marketing channel}

Most of the dry fish producers marketed the stored dry fishes normally at every 2-20 days interval which depended on the buyers (locally called paikers) and aratdars. In dry fish marketing system, a number of middlemen involved in study area. It was observed that almost all the dried fish product (95\%) carried to the arat of Chittagong, Syedpur and some parts of Dhaka from the study areas. Only (5\%) dried fishes were consumed locally and sell to the tourist (Figure 6). Between different arats, almost all the dried fish product (80\%) carried to the arat of Chittagong, then (15\%) to Syedpur and some parts (5\%) carried to Dhaka from the study area. 


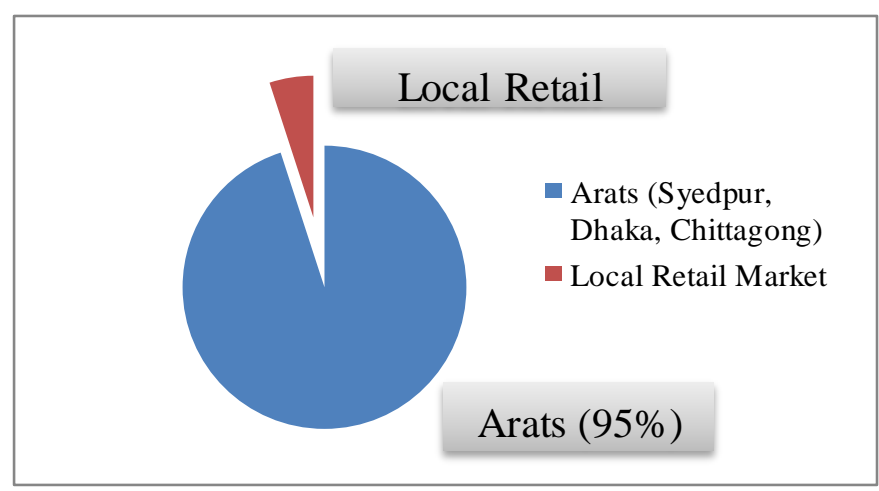

Figure 6. Distribution area of dried fish in the study area.

However, total three (3) types of dried fish marketing channels were observed during the investigation periods which were consisted dried fish producers, several middlemen (aratdar, wholesaler and retailer) and consumer (Figure 7).

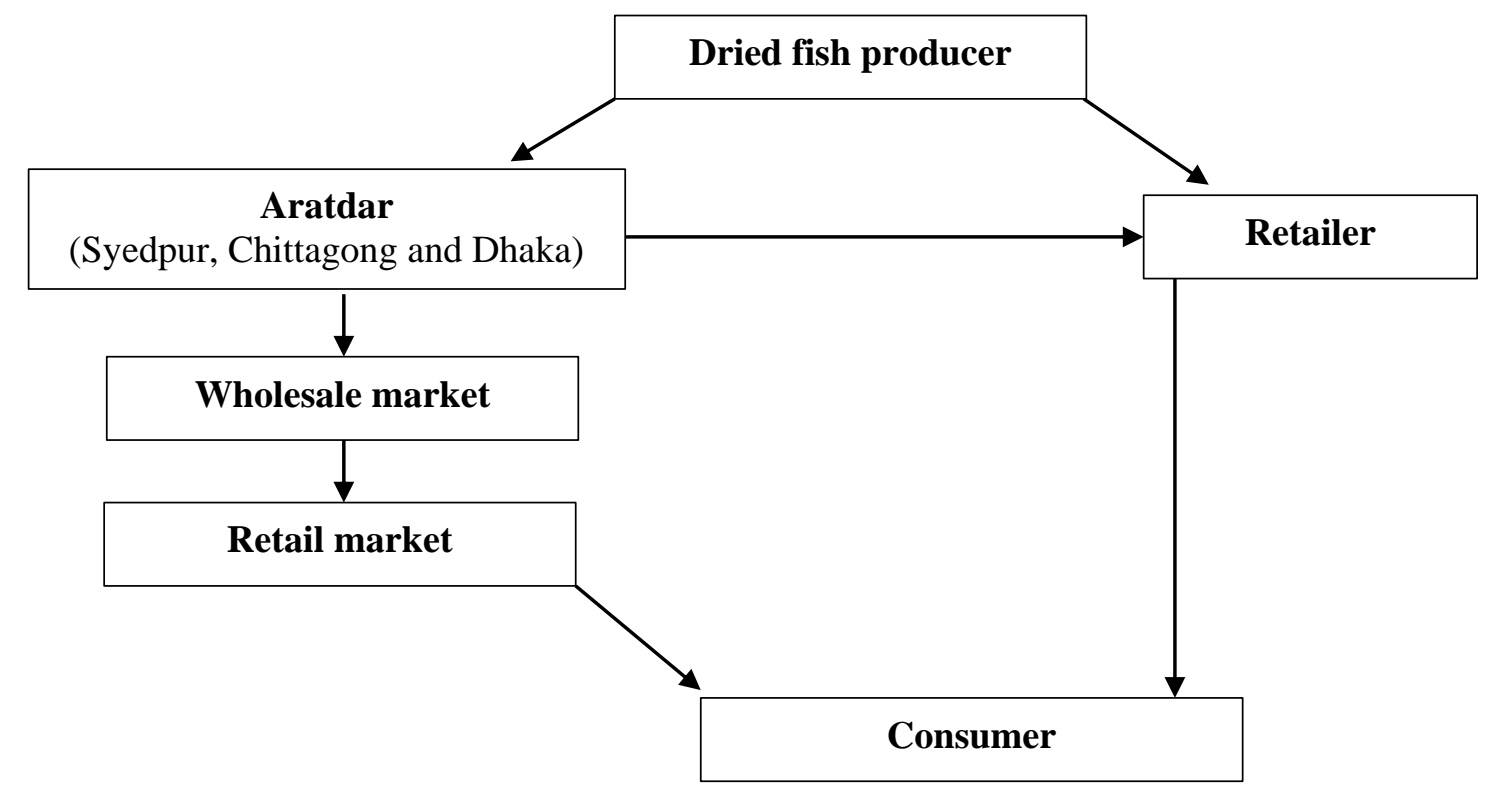

Figure 7. Marketing channel of dried fish in the study area.

The retailers of the study area buy dry fish from the dry fish producers at drying season and without drying season retailer's collect dry fish from different arat (mainly from Syedpur) and directly sell to the consumers. Locally produced dry fishes in the study area are sold to the retail market of the study area and finally go to the consumers. It was observed that retailers sometimes buy little amount of some raw fish species for drying purpose but it was depended on the price of the raw fish and the place to dry fish.

\subsection{Dried fish price}

Price of the dried fishes was found to be varied according to the species, size, quality of the final products and season (Table 2). In peak season, the prices of dried fish were lower than the other months of the year. 
Table 2. Price of the dried species in the study area at peak season (BDT/Kg).

\begin{tabular}{|c|c|c|c|c|c|c|}
\hline $\begin{array}{l}\text { Sl. } \\
\text { No. }\end{array}$ & Scientific name & Local name & $\begin{array}{l}\text { Producer Buying } \\
\text { Price with cost }\end{array}$ & $\begin{array}{l}\text { Producer } \\
\text { Selling Price }\end{array}$ & $\begin{array}{l}\text { Retail } \\
\text { markets } \\
\text { Buying Price }\end{array}$ & $\begin{array}{l}\text { Retail } \\
\text { markets } \\
\text { Selling Price }\end{array}$ \\
\hline 01 & Harpadon nehereus & Loittya & $25-35$ & $250-300$ & $250-300$ & $275-400$ \\
\hline 02 & Himantura bleekeri & Shapla pata & $150-200$ & $500-550$ & $500-600$ & $600-650$ \\
\hline \multirow[t]{2}{*}{03} & \multirow[t]{2}{*}{ Raiamas bola } & \multirow[t]{2}{*}{ Bhol } & $1700-1800$ & $1200-1500$ & $1500-1800$ & $1800-2000$ \\
\hline & & & $1700-1800$ & $70000-80000$ & - & - \\
\hline 04 & $\begin{array}{l}\text { Mastacenbelus } \\
\text { armatus }\end{array}$ & Sona bain & $500-600$ & $1800-2000$ & $2000-2200$ & $2500-2800$ \\
\hline 05 & $\begin{array}{l}\text { Scoliodon } \\
\text { sorrakowah }\end{array}$ & Hangor & $150-200$ & $500-550$ & $500-600$ & $700-1000$ \\
\hline 06 & Setipinna phasa & Modhu faissa & $30-40$ & $120-160$ & $150-160$ & $200-220$ \\
\hline 07 & Gudusia chapra & Chapila & $70-80$ & $150-200$ & $150-250$ & $200-300$ \\
\hline 08 & $\begin{array}{l}\text { Panna microdon, } \\
\text { Johnious argentatus }\end{array}$ & Poa, Lal poa & $100-150$ & $350-400$ & $400-420$ & $450-500$ \\
\hline 09 & Macrobrachium sp. & Chingri & $50-70$ & $200-250$ & $150-250$ & $200-300$ \\
\hline 10 & Lates calcarifer & Koral & $500-650$ & $1800-2000$ & $1500-1800$ & $1800-2000$ \\
\hline 11 & $\begin{array}{l}\text { Lepturacanthus } \\
\text { savala/ } \\
\text { Trichiurus lepturus }\end{array}$ & Churi & $150-200$ & $480-500$ & $600-650$ & $700-800$ \\
\hline 12 & Tenualosa ilisha & Nona Ilish & $150-200$ & $250-300$ & $250-300$ & $300-350$ \\
\hline 13 & $\begin{array}{l}\text { Polynemus } \\
\text { paradiseus/ } \\
\text { Sarotherodon } \\
\text { melanotheron } \\
\text { heudelotii }\end{array}$ & Taposi & $100-150$ & $400-450$ & $200-220$ & $250-300$ \\
\hline 14 & Devario devario & Baspata & $60-70$ & $160-200$ & $200-230$ & $230-260$ \\
\hline \multirow[t]{2}{*}{15} & \multirow{2}{*}{$\begin{array}{l}\text { Pampus chinensi/ } \\
\text { Stromateus chinensis }\end{array}$} & Rup chanda & $2600-2800$ & $3000-3200$ & $3000-3200$ & $3200-3500$ \\
\hline & & $\begin{array}{l}\text { Choto } \\
\text { rupchanda }\end{array}$ & $220-250$ & $250-300$ & $250-280$ & $300-350$ \\
\hline 16 & $\begin{array}{l}\text { Scomberomorus } \\
\text { guttatus }\end{array}$ & Surma & $500-550$ & $600-650$ & $500-550$ & $600-700$ \\
\hline 17 & Polynemus indicus & Lakka & $1500-1600$ & $1600-1800$ & $1500-1600$ & $1600-1800$ \\
\hline \multirow[t]{2}{*}{18} & \multirow{2}{*}{$\begin{array}{l}\text { Xenentodon cancilal } \\
\text { Congresox } \\
\text { talabonoidis }\end{array}$} & \multirow[t]{2}{*}{ Kaikla/Kamila } & $350-400$ & $400-420$ & $400-450$ & $450-500$ \\
\hline & & & $350-400$ & $25000-26000$ & - & - \\
\hline 19 & Katsuwonus pelamis & Rupsha & $150-200$ & $420-450$ & $400-450$ & $500-550$ \\
\hline 20 & Mugil cephalus & Bata & $300-320$ & $500-550$ & $500-550$ & $600-650$ \\
\hline 21 & Mystus sp. & Tengra, Kata & $150-200$ & $600-650$ & $650-700$ & $700-750$ \\
\hline
\end{tabular}

The retail price of the dried fishes was ranged from Tk. 200-3500 per Kg. During the study period the highest price of the dried fishes was found Tk. 3200-3500 per Kg for Rup chanda (Pampus chinensis) because the producers was gotten a limited amount of raw fish and the price of the raw fish was high and the lowest was Tk. 200-220 per Kg for Modhu faissa in the study area because of raw fish availability and the price of the raw fish was lowest at peak drying season (Table 2). The seasonal income of drying enterprise might vary from area to area. This variation was due to the raw material availability, processing cost and demand of the consumers. Sometimes the dry fish producers were dried the air bladder of some fishes such as Kaikla (Xenentodon cancila), Bhol (Raiamas bola) fish etc. because producers get an extra benefit by selling dried air bladder. But due to high price of dried air bladder the retailers of Kuakata didn't sell this product. The dry fish producers didn't produce dry Kaski (Sicamugil cascasia) due to unavailability of raw fish. The dry fish retailers of Kuakata were taken dry kaski from different whole sale market of Bangladesh. The retail markets buying price of the dried Kaski was ranged from Tk. 150-200 per Kg and selling price was ranged from Tk. 200-300 per Kg. The difference in income range might be due to the scale of drying activities, raw materials availability and the consumer preference about dried fish in certain area. Therefore, it was very much profitable and suitable businesses in this area as the seasonal fishes were available during glut catch. 
3.8. Problems of dry fish producers and retailers

Several marketing problems were found in dry fish marketing which includes:

1. Lack of capital

2. Natural calamities like unexpected rain, cyclone

3. Lack of scientific knowledge and technology

4. Price instability \& Lack of physical marketing facilities

5. Lack of marketing information

6. Higher transportation cost

7. Storage problem

8. Inadequate extension services

9. Lower market demand and

10. Higher loan interest rate etc.

The responses of different problems on fish drying and marketing activities in the study area by the dry fish producers and retailers are showed in Table 3.

Table 3. Different problems on fish drying and marketing activities in the study area.

\begin{tabular}{|l|l|l|l|l|l|l|l|l|}
\hline Sl. No. & Problems & VC & $\mathbf{C}^{*}$ & EC & NC* & Scores & Points & Remarks \\
\hline 01 & Lack of capital & 28 & 5 & - & - & 127 & 3.85 & Critical \\
\hline 02 & Natural calamities like unexpected rain & 26 & 4 & 3 & - & 122 & 3.70 & Critical \\
\hline 03 & Lack of scientific knowledge and technology & 15 & 10 & 5 & 2 & 102 & 3.19 & Critical \\
\hline 04 & Price instability & 20 & 10 & 1 & 3 & 116 & 3.41 & Critical \\
\hline 05 & Lack of physical marketing facilities & 24 & 2 & 1 & - & 140 & 3.85 & Critical \\
\hline 06 & Lack of marketing information & 2 & 15 & 10 & 6 & 79 & 2.39 & Not Critical \\
\hline 07 & Higher transportation cost & - & 10 & 11 & 8 & 60 & 2.07 & Not Critical \\
\hline 08 & Storage problem & 20 & 7 & 3 & - & 107 & 3.57 & Critical \\
\hline 09 & Inadequate extension services & - & 5 & 13 & 13 & 54 & 1.74 & Not Critical \\
\hline 10 & Lower market demand & 20 & 5 & 4 & - & 103 & 3.55 & Critical \\
\hline 11 & Higher loan interest rate & 3 & 8 & 10 & 3 & 59 & 2.46 & Not Critical \\
\hline
\end{tabular}

*VC=Very critical, $\mathrm{C}=$ Critical, $\mathrm{EC}=$ Extent Critical, $\mathrm{NC}=$ Not Critical

The dry fish producer share of the wholesale price was not low and this can further increase by improving marketing facilities and eliminating unnecessary and inefficient and exploitative middlemen from the marketing channel.

\section{Discussion}

Variety of fishes is being used in sun drying in the study areas. For commercial sun drying species selection depends on both availability and market demand. Reza et al. (2005) conducted a study on traditional drying activities of commercially important marine fishes of Bangladesh and found poor quality raw materials were used for drying which coincides with the findings of the present study. Latif et al. (1983) studied on the status of the dried fish processing industry in the East Coast states of Kelantan and Terengganu where most producers agreed that freshness of fish before processing was a very important factor in producing good quality dried fish which agreed with the present finding.

Faruque et al. (2012) found that Loittya (Harpadon nehereus), Poa (Panna microdon), Phasa (Setipinna phasa), Taposi (Polynemus paradiseus), Chhuri (Lepturacanthus savala), Boiragi (Coilia dussumieri), Fatra (Raconda russeliana), Rupchanda (Pampus chinensis), Pama (Otolithes pama) as major fish species used for drying which was more or less similar to our findings. Nowsad (2004) also found more less similar drying species in coastal Cox's Bazar. In the study area drying were done seasonally. Flowra et al. (2012) also found most of the fish drying points were operated seasonally (from July to March) where the peak period of drying was September to October. It was also observed that some dry fish producers did not wash properly of their raw fishes. The small fishes were found to be dry directly under the sun without any dressing and washing. This finding agreed with the findings with Samad et al. (2009). The large fishes were found to practice for gutting and splitting. It was observed that sometimes low-quality damaged fishes were brought from landing centers for drying. Each dry fish producer gathered required amount of fresh fish for sun drying which depended on availability of raw fish in landing centers and price of raw fish also. Sorting of raw fish could be varying from area to area. Flowra $e t$ 
al. (2012) reported that sorting of dried fish was common in Chalan Beel areas of Bangladesh because sorting was also performed after collection of raw fishes for drying. Generally, dry fish producers used commercial salts for drying purpose and most of the dried fish producers did not maintain any fixed ratio for salting the fish. If the dry fish producers were collected raw fish at night then used a little greater amount of salt to keep raw fish at fresh condition then if they were collected raw fish at day time. Addition of salt was also practiced in the study areas. But mainly low-quality salt was used. Suparno (1994) reported that, the use of solar and impure salt in fish drying in Indonesia was a source of halophilic bacteria and affected salt penetration into the fish flesh. In the study area, drying process varied according to the size and type of fishes as well as choice of consumers. In the study sites, dry fish producers used high amount of salt in raw fish mainly in the cloudy weather than normal weather. Sometimes large fishes such as coral fish were cut into small pieces and keep on the rack for drying. However, more or less similar findings were also found by Flowra et al. (2012) and Shamim et al. (2014). Sugathapala et al. (2012) also studied about salt based dry fish processing and marketing by fishers of Minneriya reservoir in Sri Lanka. Salt was used less amount in fish of study area than Sugathapala et al. (2012). This might be due to the climatic condition of Bangladesh as during the drying season, moisture content of air was comparatively less and it took comparatively fewer days to complete drying. Drying duration varied according to the weather conditions like intensity of sunlight, temperature, relative humidity and wind flow, status of rain and duration of day. It was found that at normal weather condition duration of drying varied between 3-5 days depending on the size of fishes in the study area. Other similar studies conducted in Chalan Beel areas of Bangladesh (Flowra et al., 2012; Samad et al., 2009) on fish drying also reported the drying duration recorded to be varied from 2-6 days depending on the size of the raw fishes at normal weather condition, which are in concert with this study findings. The sun drying process agrees with the findings of Samad et al. (2009) where people of Chalan Beel areas carried out their drying activities on bamboo rack or fishing net directly on earth for business purpose. However, more or less similar findings for methods of sun drying were also found by Shamim et al. (2014). Soegiyono (1994) also reported that traditional sun drying was carried out in trays, where fishes were arranged sequentially. When the fishes were dry enough on one side, they were turned upside down to complete the drying process.

Normally dry fish producers get $30-35 \mathrm{Kg}$ dry fish from $100 \mathrm{Kg}$ raw fish. Sometimes the products were found to be contaminated with soil, dirt and blow fly. Reza et al. (2005) studied about traditional drying of marine fishes of Bangladesh where commercial drying was carried out in sandy beaches of Cox's Bazar region, where fishes were contaminated with sand, blowflies and microorganisms. Bhat et al. (2013) conducted a study in district Bandipora of Kashmir valley and reported the conventional method employed in drying of fishes was unscientific and can cause serious health hazards and more or less similar studies was also conducted by Immaculate et al. (2013), where they found the poor quality of dried fishes were mainly due to unhygienic processing and drying methods, inadequate salting, use of spoiled fish for processing and lack of air tight packing of the dried fishes which was more or less similar of the present study. Sometimes dry fish producers were found to use insecticides in raw fishes before drying for preventing from insect infestation. Reza et al. (2005) studied about some commercial important marine dried fishes of Bangladesh where they observed raw fishes were soaked in various types of insecticides including DDT and Nogos before drying. Samad et al. (2009) reported that the bagged dried fishes were kept into the tents generally made of thin plastic sheet and bamboo splits for temporary storage until marketing or selling. In the tropical region like Bangladesh, the finished sundried fish products are typical and its shape and structure make it almost impossible to pack well enough to prevent uptake of water and consequently some degree of spoilage is almost inevitable during storage. Therefore, it may be postulated that dried fish products even with low moisture content stored under no protection against high humidity can be the vehicle for most of the important types of bacteria responsible for food spoilage. The marketing channel of dry fishes is started from the producer and then go to aratder, wholesalers, retailers and finally up to consumers or from the producer to retailer and finally up to consumers. The present result is similar with Samad et al. (2009) and More or less similar findings were also found by Flowra et al. (2010), Marine et al. (2014) and Shamim et al. (2014).

Pricing usually depends on the product average costs. Price of the dried fish varied on the size and quality of the product. Faruque et al. (2012) found that more or less similar price of major dried marine fish at Asadganj dry fish market which is in agreement to our result.

Several major problems were identified in the study area. Fersoushi et al. (2015) also identified comparable problems in dry fish marketing of Rangpur division. Ahmed et al. (2007) also reported that traders of tilapia marketing faced the problems of poor road and transport facilities, higher transport costs, insufficient supply of ice, unhygienic conditions, lack of credit facilities, poor infrastructure of markets, political disturbances such as 
strikes and road blocks, etc. It is therefore necessary to provide institutional and organizational support, extension services and more research along with knowledge of dried fish marketing.

\section{Conclusions}

Marine dried fish production and marketing plays an important role in the economy of Bangladesh, contributing to increased food production, diversification of the economy and increased employment opportunities. In most of the observed fish drying places, sun drying is carried out in an unhygienic condition. No dressing of used fishes in many cases; drying directly on earth surface which affect the quality of dried product strongly. Sometimes dry fish producer used insecticides for protecting raw fish from insect attack. This practice greatly affects the quality of final product which is very harmful for human health too. Moisture, dust and other harmful substances from the environment can easily be mixed to the fish and make the fish susceptible to the microorganism or insect attack. In the present study, poor quality and inadequate infrastructure in wholesale and retail market were identified. In most cases, storage of dried fish in unhygienic condition was observed which usually took place in the tent having no platform. Furthermore, it was also found that raw and dried products were kept in the same tent which badly affects the quality of dried final product. The requirement of a satisfactory dried product is highly desirable and to achieve this, scientific drying method should be practiced in all the drying process. Extension work needs to be done so that there is awareness from dry fish producers to consumers on handling procedures and quality regulations to ensure reduction in losses and quality of product to market.

\section{Acknowledgements}

The author expresses his heart squeezed gratitude, indebtedness and sincere appreciation to Research and Training Center of Patuakhali Science and Technology University and all beloved teachers, for valuable suggestion and co-operations during the study. The author also expressed his thanks to aratdars and retail owners of the study area.

\section{Conflict of interest}

None to declare.

\section{References}

Ahmed M, AD Bhuiyan, AMS Alam and Huda SMS, 1978. Radiation disinfestation studies on sun-dried fish. Indo-pacific Fishery Commission, Proceeding 18 session, Manila, Philippines 8-17 March, pp. 310-321.

Ahmed M, MN Islam and M Shamsuddoha, 2007. Value chain analysis in the dry fish production and marketing of Post Harvest Fishery Products (PHFP) in the coastal belt of Bangladesh. Bangladesh Fisheries Research Forum, Mymensingh, Bangladesh.

Amin MA, MR Islam and MB Hossain, 2012. Marketing channel of dried marine fish in the southeastern coastal belt of Bangladesh. Middle-East Journal of Scientific Research, 12: 301-306.

Azim MA, MR Islam, MB Hossain and MH Minar, 2012. Seasonal variation in the proximate composition of gangetic sillago, Sillaginopsis panijus (Perciformes: Sillaginidae), Middle-east J. Sci. storage. Food and Res., 11: 559-562.

Bhat TH, Rizwana, MH Balkhi and BA Bhat, 2013. An investigation on the indigenous method of fish drying in Bandipora district of Kashmir valley, J. Chem. Biol. Phy. Sci., 3: 1927-1932.

DoF, 2015. Fisheries Statistical Yearbook 2013-2014, Department of Fisheries, Ministry of Fisheries and Livestock, Dhaka, Bangladesh.

DoF, 2018. Yearbook of Fisheries Statistics of Bangladesh, 2017-18. Fisheries Resources Survey System (FRSS), Department of Fisheries. Bangladesh: Ministry of Fisheries, 2018. Volume 35, pp. 129

Faruque MO, KMS Nazrul, US Tonny, KHR Islam, SC Dey, SJ Mona and D Saha, 2012. Status of an ideal dry fish market of Bangladesh: a study on asadganj dry fish market, Chittagong. Int. J. Life Sc. Bt \& Pharm. Res., 1: 214-225.

Ferdose, A Hossain and MB Hossain, 2011. Nutritional value of wild, cultured and frozen prawn Macrobrachium rosenbergii (De Man, 1879). Int. J. of Nat. Sci., 1: 52-55.

Fersoushi Z, M Rashed, MA Zafar, VC Roy and S Islam, 2015. Species availability and marketing system of traditionally dried fish in Rangpur division of Bangladesh, International Journal of Fisheries and Aquatic Studies, 3:178-183.

Flowra FA, MS Mohmud and RC Mondal, 2012. Traditional fish drying activities and socio-economic status of dried fish producers of Chalan Beel area, Sirajganj, Bangladesh, Bang. J. Prog. Sci. Tech., 10: 65-68. 
Flowra FA, SC Sen, SM Galib, MM Kamal and SN Islam, 2010. Dry fish marketing in Rajshahi and Thakurgaon, Bangladesh. International Journal of Bio Research, 1: 13-16.

Hafiza NA, 2008. Dry fish marketing system in selected areas of Mymensingh and Netrokona Districts, M.S. Thesis, Department of Co-operation and Marketing, Bangladesh Agricultural University, Mymensingh.

Hossain MG and MA Hossain, 1999. Controlled breeding technology and step for conservation of gene pool of certain endangered fish species of Bangladesh, Fisheries Newslett., 7, pp. 2-3.

Immaculate K, P Sinduja, A Velammal and P Jamila, 2013. Quality and shelf life status of salted and sun-dried fishes of Tuticorin fishing villages in different seasons. Int. Food Res. J., 20: 1855-1863.

Kleih U, K Alam, R Dastidar, U Dutta, N Oudwater and Ward A, 2003. Livelihoods in coastal fishing communities, and the marine fish marketing system of Bangladesh. NRI Report No. 2712. Greenwich University, Natural Resources Institute, London.

Latif, Kamariah, Ismail, M Salleh, Yassin, Zaiton, Bardaie and Zohadie, 1983. Production of dried fish in the east coast of Peninsular Malaysia - a survey. In: Workshop on the Production and Storage of Dried Fish, 2-5 November 1982, UPM, Serdang.

Marine SS, MA Hossain, R Rashid, MA Islam and SM Bari, 2014. Marketing strategies for dry fish in Sylhet district of Bangladesh. Bangladesh Research Publication Journal, 10: 162-169.

Monir MS, MR Haque and S Rahman, 2012. Dry fish marketing in Nilphamary district of Bangladesh. Journal of Science and Technology, 11: 32-36.

Nayeem MA, K Parvin, MS Reza, MNA Khan, MN Islam and M Kamal, 2010. Marketing system of traditional dried and semi-fermented fish product (chepa shutki) and socioeconomic condition of the retailers in local markets of Mymensingh division, Bangladesh Research Publication Journal, 4: 69-75.

Nowsad AKMA, 2004. Traditional fish drying in coastal villages of Bangladesh: Practices, constraints and scope for improvements. Food and Agriculture Organization of the United Nations, Dhaka, pp. 80.

Nowsad AKMA, 2005. Low cost processing of fish in coastal Bangladesh, BGD/97/207 Field Doc: 05/2005. Food and Agriculture Organization of the United Nation. Dhaka, pp. 73.

Nowsad AKMA, 2007. Participatory Training of Trainers: A new approach applied in fish processing. Bengal Com-print, 68/5, Green Road, Dhaka, Bangladesh.

Rahman AKA, 1989. Freshwater fishes of Bangladesh. Zoology Society of Bangladesh, Dhaka.

Reza SM, MAJ Bapary, KM Azimuddin, M Nurullah and M Kamal, 2005. Studies on the traditional drying activities of commercial important marine fishes of Bangladesh. Pak. J. Biol. Sci., 8: 1303-1310.

Reza SM, M Kamal, M Akteruzzaman and MN Islam, 2005. Presentation of drying activities of marine fishes in the coastal division of Bangladesh, Bangladesh Journal of Fisheries, pp. 27-46.

Samad MA, SM Galib and FA Flowra, 2009. Fish drying in Chalan Beel areas, Bangladesh. J. Sci. Ind. Res, 44: 461-466.

Shamim S, MM Ali, MS Monir, MAU Doulah and MG Sarwer, 2014. Traditional fish drying activities and marketing status of dried fish at Tarash upazila under Sirajganj district of Bangladesh. Marine Res. Aqua., 2: 32-37.

Shamsuddin M, MB Hossain, MM Rahman, A Mand and MY Ali, 2012. Performance of monosex fry production of two nile tilapia strains: GIFT and NEW GIPU. World Journal of Fish and Marine Sciences, 4: 68-72.

Soegiyono, 1994. Problems associated with dried fish agribusiness in Indonesia, pp. 21. In: Champ BR, Highley (eds.), 1995. Fish drying in Indonesia. Proceedings of an international workshop held at Jakarta, Indonesia. 910 February 1994. ACIAR Proceedings No. 59, p106.

Sugathapala RMNS, TV Suntharabarathy and U Edirisinghe, 2012. Salt based dry fish processing and marketing by fishers of minneriya reservoir in SriLanka, Trop. Agr. Res, 23: 357-362.

Sultana N, 2011. Availability and marketing of dry and cheapa fish in Mymensingh. MS thesis, Department of Aquaculture, Bangladesh Agricultural University.

Suparno, 1994. Fish salting and drying studies in Indonesia. pp. 61-62. In: Champ BR, Highley (eds.), 1995. Fish drying in Indonesia. Proceedings of an international workshop held at Jakarta, Indonesia. 9-10 February 1994, ACIAR Proceedings No. 59, pp.106. 